\title{
A Team-games Tournament (TGT) Learning Model with Narikiri Technique in Shokyu Chokai Subjects
}

\author{
Rachmidian Rahayu ${ }^{1}$, Rina Yuniastuti ${ }^{2}$ \\ \{rachmidianrahayu@hum.unand.ac.id $\left.{ }^{2}\right\}$ \\ 1,2 Japanese Language Department, Universitas Andalas, Padang, Indonesia
}

\begin{abstract}
Shokyuu Choukai is a mandatory Japanese subject intended for second semester students. Cooperative learning method is performed in the form of team-games tournament (TGT) learning model with narikiri technique. Narikiri is an imitating drill technique to pronounce words as accurate as Japanese native speakers. There are some steps applied which the lecturer explains about team games tournament and narikiri technique. The students will divide into 8 teams where each team involved four students. Each team received the audio and the cards that contains audio material. Each team member took note, listen the audio, and pronounce the words in the audio. Tournament was done by one team reading the audio material in front of the class, then the other teams listen and answer the questions. The observation and interview were conducted in order to know the effectiveness of this learning model. The result shows that the use learning process was successfully done by using team-games tournament technique. It can be seen from the increasing of students' learning outcomes where students' listening ability are improved and students are motivated to follow the lecture.
\end{abstract}

Keywords: Teams Games Tournament, Narikiri, Shokyuu Choukai.

\section{Introduction}

Great communication skills--oral and written--in learning foreign language can be acquired through four essential skills (gengo nooryoku). They are listening (kiku nooryoku), speaking (hanasu nooryoku), reading (yomu nooryoku), and writing (rigid nooryok) [1] . Japanese language department in Andalas University has accommodated the process of mastering those skills through standard textbooks.

In the curriculum of Japanese Language Department, Faculty of Cultural Science, Andalas University, cultivating students' listening skill is implemented in Choukai. Moreover, Shokyuu Choukai is a listening subject for beginners. Shokyuu Choukai subject is intended for second semester students. However, those who take the Shokyuu Choukai must have accomplished Choukai Nyuumon in the first semester. The prospective students are expected to be proficient in hiragana, katakana, basic kanji, and bun po (basic and advanced grammar).

Based on learning outcomes that have been set in motion for listening skill, second semester students should be able to understand familiar phrase. Similarly, they can communicate in single or short sentences which had already prepared. If the materials were not prepared in advance, they are expected to express it in simple phrase or sentences, for 
example: describing their address or person. They also own unrelated basic vocabulary and specific expressions. Furthermore, they are able to naturally manipulate speech pauses to keep the conversation going while in the same time brainstorming for the appropriate diction or expression.

Prior lectures had integrated both Teacher Center Learning (TCL) and Student Learning Center (SCL) methods in teaching learning process. In the earlier process, the lecturer asked the students to listen to the audio and complete the exercise given. Obviously, this method is only focusing on listening skill while neglecting speaking skill. Then, the lecturer would ask relating to topic on the audio while students directly, responded. Due to time limitation, not all of them can participate in discussion.

The previous assessment was focused on mid-term exam and final exam. The results may vary from D to A. It indicates that the assessment is result oriented. Consequently, it fails to analyze students' comprehension toward learning materials.

Thus, it needs a new learning model that able to facilitate both listening and speaking skills in Shokyuu Choukai. In Shokyuu Choukai subject, students need to master 17 chapters from two main textbooks, Minna no Nihongo and Tasuku 25. Since the scheduled face-to-face class meetings are not sufficient, TGT learning model with Narikiri technique plays its role. Not only will the students comprehend the materials but also actively involved in free discussion.

\section{Methods}

The learning model used in Shokyuu Choukai is TGT with narikiri technique. TGT is one of cooperative learning method that emphasizes on teams' activities, the students work in a group and challenge others in academic tournament table [4]. He added, team-gamestournament, as cooperative learning method, consists of 5 phases: class presentation, team learning, games, tournament, and team recognition. As for Narikiri, according to [1] narikiri technique is a role-based listening technique.

This study combined and modified TGT learning model with narikiri technique to fulfill Shokyuu Choukai subject needs. The writers also conducted pretest post-test control research design in three steps which was advised by [3] :

1. Conducting pretest to analyze students' listening skill before the main treatment.

2. Applying treatment: TGT learning model with narikiri technique.

3. Conducting post-test to analyze learning model's effectiveness.

The results of pretest and post-test were analyzed using the following formula:

$$
\bar{x}=\frac{\sum x}{n}
$$

Information:

$\bar{x}=$ Students' average score.

$\sum x$

$=$ total number all students

$n=$ total students

The test results show that there is significant effectiveness in using TGT learning model with narikiri techniques 
This research was conducted in three months, from March to May 2019. It took place in two places in Japanese Language Department buildings, language laboratory for teaching and learning process and seminar room for tournament.

To make a good use of this learning model, these things need to be considered further:

1. Lesson Plan

The previous lesson plan was revised. Thus, the new lesson plan is expected to serve as better guideline and implement TGT learning model with narikiri technique. This learning model should be able to facilitate students in boosting their motivation, and participating in formal-informal discussion. As a result, both students' listening and speaking skills in Japanese will be enhanced.

\section{Implementation}

This study aimed to implement TGT learning model with narikiri technique in Shokyuu Choukai subject. It also provided the results of the pretest and post-test for listening. The result was taken as a tool to measure change in students' score.

After the pretest, TCL and SCL methods were still carried out while the lecturer conducted an observation. On the 12th meeting, the main treatment began:

1. Class Presentation

The first thing to do was introducing narikiri technique. Narikiri is a Japanese term for imitating. Students imitated how Japanese native speakers pronounce words. The students soon did repetitive drill, listening to the audio, understanding the dialogue, and producing the exact same words repeatedly. Then, the lecturer introduced TGT, a cooperative learning strategy and assigned the students to work in a group to compete in academic games.

\section{Team}

There were 32 students which divided into eight teams of 4 students respectively. The team was selected through random pick. After that, the lecture took out 8 team cards, the card should has distinguished color. The card contains learning material which is compatible with the given audio. Each team will listen to the audio, take note, and practice the dialogue as they were native speaker. The teams are in charge of themselves. They must ensure all member were listening to the audio repeatedly, understanding the dialogue, and practicing to pronounce the sentences like a Japanese native speaker. Finally, the team should complete the incomplete written dialogue given.

\section{Game}

The game consists of several questions which were written in the team cards. It was designed so the students listen to the audio and imitate it well.

\section{Tournaments}

The tournament was held in additional class meeting since the official 16 meetings were solely for lectures. The tournament was included in the game. A team will read out the whole questions from the audio while others try to write the answers in their own team cards. 


\section{Team recognition}

The team gained a score based on individual strength in answering opponent team questions. After all the questions were answered, each student counted the score, added it to the team score and calculated the average score. Hence, the final score would be revealed.

\section{Research Findings}

Pretest and post-test were conducted to complete this research. This is the average score of students' pretest result.

\begin{tabular}{|c|c|c|c|}
\hline No. & Students' Name & Students' Reg. Number & Score \\
\hline 1 & MUTIA NOVA ELIZA & 1810751002 & 82 \\
\hline 2 & MUHAMMAD ILHAM & 1810751004 & 58 \\
\hline 3 & MUTIARA RANI & 1810751006 & 80 \\
\hline 4 & DEBBY CHANDRA & 1810751008 & 94 \\
\hline 5 & VIRA SANTIKA & 1810751010 & 80 \\
\hline 6 & ENNI SAHRONI SIMATUPANG & 1810751012 & 78 \\
\hline 7 & KRIS RAHAYU & 1810751014 & 96 \\
\hline 8 & TEGUH NANDA MULIA & 1810751016 & 76 \\
\hline 9 & ARMENDA RAHMA FITRI & 1810751018 & 84 \\
\hline 10 & SYAFNI WITHARI & 1810751020 & 76 \\
\hline 11 & FADIA HAYA RAHMI & 1810751020 & 86 \\
\hline 12 & RIJALUL FAJRI & 1810752002 & 78 \\
\hline 13 & MUHAMMAD HANAFI & 1810752004 & 92 \\
\hline 14 & WIDYA ZAREFRI & 1810752006 & 88 \\
\hline 15 & FETRI NURAINI & 1810752008 & 96 \\
\hline 16 & DEA RISKIMAILA & 1810752010 & 62 \\
\hline 17 & TAMIRA APRILIA SYAFIR & 1810752012 & 92 \\
\hline 18 & KHOLISA & 1810752014 & 94 \\
\hline 19 & NURLIO MARYUSDA & 1810752016 & 70 \\
\hline 20 & FADHULLAH HABBI & 1810752020 & 96 \\
\hline 21 & SINTA MURMAILA & 1810752022 & 44 \\
\hline 22 & YOURI AUDRYAN TANJUNG & 1810752024 & 98 \\
\hline 23 & FENY FATRIANI & 1810752026 & 78 \\
\hline 24 & ADINDA PUTRI SALSABILA & 1810752028 & 84 \\
\hline 25 & MUHAMMAD ANSHARI & 1810752030 & 100 \\
\hline 26 & RAJATI OKTAVIRA & 1810752032 & 82 \\
\hline 27 & FARHAN & 1810752034 & 74 \\
\hline 28 & JODI SYAFDA CANDRA & 1810752036 & 84 \\
\hline 29 & RAYHAN HELMI & 1810752038 & 96 \\
\hline 30 & MUHAMMAD DAFA & 1810753002 & 88 \\
\hline 31 & YUDHI KURNIAWAN & 1810753004 & 76 \\
\hline \multirow[t]{2}{*}{32} & DAFFA AYASH & 1810753006 & 74 \\
\hline & & Total & 2636 \\
\hline
\end{tabular}


Pretest average score for 32 students:

$\frac{2636}{32}=79.87$

Thus, the total score for 32 students is 2636 and the average score for pretest is 79,87 . The next phase taken is implementing the treatment by using TGT learning model with narikiri technique.

The exercises were distributed as follow: The first team got Exercise 4, The second team had Exercise 7. The third team did Exercise 3. The fourth team dealt with Exercise 6. The fifth team worked on Exercise 2. The sixth team got exercise 1. The seventh did Exercise 8 and the last team had Exercise 5. After all team received the structured exercises, the lecturer will start the audio.

\begin{tabular}{llll}
\hline No & Student's Name & Students' Reg. Number & Post-test Score \\
\hline 1 & MUTIA NOVA ELIZA & 1810751002 & 92 \\
2 & MUHAMMAD ILHAM & 1810751004 & 88 \\
3 & MUTIARA RANI & 1810751006 & 97 \\
4 & DEBBY CHANDRA & 1810751008 & 66 \\
5 & VIRA SANTIKA & 1810751010 & 96 \\
6 & ENNI SAHRONI SIMATUPANG & 1810751012 & 88 \\
7 & KRIS RAHAYU & 1810751014 & 78 \\
8 & TEGUH NANDA MULIA & 1810751016 & 93 \\
9 & ARMENDA RAHMA FITRI & 1810751018 & 78 \\
10 & SYAFNI WITHARI & 1810751020 & 86 \\
11 & FADIA HAYA RAHMI & 1810751020 & 89 \\
12 & RIJALUL FAJRI & 1810752002 & 51 \\
13 & MUHAMMAD HANAFI & 1810752004 & 100 \\
14 & WIDYA ZAREFRI & 1810752006 & 88 \\
15 & FETRI NURAINI & 1810752008 & 96 \\
16 & DEA RISKIMAILA & 1810752010 & 64 \\
17 & TAMIRA APRILIA SYAFIR & 1810752012 & 67 \\
18 & KHOLISA & 1810752014 & 96 \\
19 & NURLIO MARYUSDA & 1810752016 & 71 \\
20 & FADHULLAH HABBI & 1810752020 & 92 \\
21 & SINTA MURMAILA & 1810752022 & 93 \\
22 & YOURI AUDRYAN TANJUNG & 1810752024 & 93 \\
23 & FENY FATRIANI & 1810752026 & 96 \\
24 & ADINDA PUTRI SALSABILA & 1810752028 & 99 \\
25 & MUHAMMAD ANSHARI & 1810752030 & \\
26 & RAJATI OKTAVIRA & 1810752032 & 93 \\
27 & FARHAN & 1810752034 & 1810752036 \\
28 & JODI SYAFDA CANDRA & & \\
& & & 93 \\
\end{tabular}




\begin{tabular}{llll}
\hline 29 & RAYHAN HELMI & 1810752038 & 92 \\
30 & MUHAMMAD DAFA & 1810753002 & 50 \\
31 & YUDHI KURNIAWAN & 1810753004 & 89 \\
32 & DAFFA AYASH & 1810753006 & 95 \\
& & Total & 2711 \\
\hline
\end{tabular}

Without overlooking the minor obstacle, the whole implementation of TGT learning model with narikiri technique was conducted well. All team were instructed to listen to the audio repeatedly, answer the questions, take note in hiragana or katakana and pronounce the words until they produced similar sound like Japanese native speaker.

When the tournament finally started, students who took their time drilling in listening and pronouncing the given materials can be visibly observed. Likewise, those who practice answering and writing in Japanese can be seen from the written answers and notes. Some were still struggling to find the correct written form, some wrote it in Latin, and others found it was hard to write hiragana or katakana quickly.

The main learning objective in Shokyuu Choukai subject is when the students understand the repeated spoken expression. The given audio will enhance students listening skill. Moreover, students were instructed to pronounce the whole words. Thus, this learning model can be used to enhance both listening and speaking.

Using this learning model, students also improve their soft skills, intrapersonal and interpersonal skills. Students can recognize their own weakness through various exercises given in listening, speaking, or writing. Students were also responsible to complete the instructed assignment.

Interpersonal skills that could be acquired through this learning model are teamwork, selfcontrol, appreciate others and mutual respect. Right after the completion of team tournament, students reflected what they have learned and participated in post-test. The test result came out with satisfying increase in average score. The test result can be seen in this following table,

Post-test average score of students:

$$
\frac{2711}{32}=82
$$

The total post-test score was 2711 and the average grade of 32 students was 82 . Thus, there was a slight increase in the average score from pretest to post-test by 2.13 points. It indicates that the learning model failed to manifest students' ability further.

However, students revealed in interviews that they prefer TGT learning model with narikiri technique than the common drill. The main reasons are: First, this learning model instructs them in listening drill, and they feel motivated to find out the gist of the conversation in the audio. (find the appropriate diction and determine the grammar). Second, selfrecognition in mastering four essential skills. The last one is interactive learning atmosphere.

\section{Conclusion}

Teams Games Tournament (TGT) learning model is one of cooperative learning strategies. TGT learning model with narikiri technique implemented in Shokyuu Choukai subject is mainly focused on role-play. Students imitates how Japanese native speaker pronounce the words. In this learning model, students are actively engaged in interactive 
classroom and self-study. This learning model also facilitates students in acquiring soft skills, intrapersonal and interpersonal. It is also expected to motivate students to be active not only in the classroom, but also outside the classroom.

\section{References}

[1] Endo, Orie. (2011). Nihongo Kyoiku o Manabu; Sono Rekisi Kara Genba Made. Tokyo: Sanshusa.

[2] Kamada dkk, (2016). Chuиkyuu Kara Jokyuu e no Nihongo Narikiri Risuninggu. Japan: The Japan Times.

[3] Arikunto, Suharsimi. (2007). Manajemen Penelitian. Jakarta: PT. Rineka Cipta.

[4] Slavin, Robert. (2009). Cooperative Learning; Teori, Riset, dan Praktik. Bandung: Nusa Media. 